\title{
DICER1 wt Allele
}

National Cancer Institute

\section{Source}

National Cancer Institute. DICER1 wt Allele. NCI Thesaurus. Code C49380.

Human DICER1 wild-type allele is located in the vicinity of 14 q32.13 and is approximately

$71 \mathrm{~kb}$ in length. This allele, which encodes endoribonuclease Dicer protein, plays a role in the RNA interference pathway via cleavage of double-stranded RNA. 